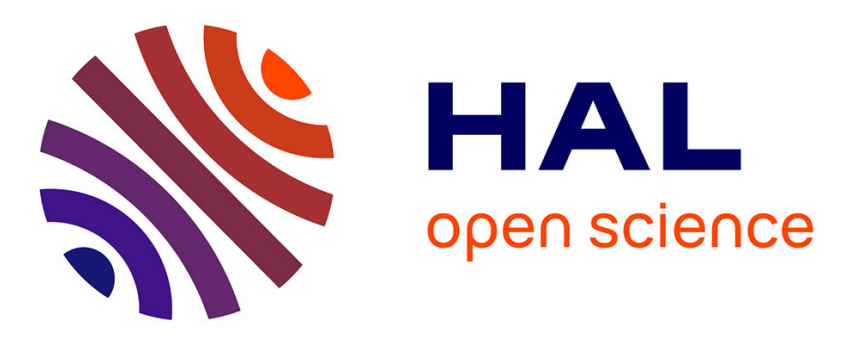

\title{
Hybridization, fertility and herbicide resistance of hybrids between wheat and Aegilops biuncialis
}

Iñigo Loureiro, Concepción Escorial, José María García-Baudin, Cristina

Chueca

\section{- To cite this version:}

Iñigo Loureiro, Concepción Escorial, José María García-Baudin, Cristina Chueca. Hybridization, fertility and herbicide resistance of hybrids between wheat and Aegilops biuncialis. Agronomy for Sustainable Development, 2009, 29 (2), pp.237-245. hal-00886480

\section{HAL Id: hal-00886480 https://hal.science/hal-00886480}

Submitted on 1 Jan 2009

HAL is a multi-disciplinary open access archive for the deposit and dissemination of scientific research documents, whether they are published or not. The documents may come from teaching and research institutions in France or abroad, or from public or private research centers.
L'archive ouverte pluridisciplinaire HAL, est destinée au dépôt et à la diffusion de documents scientifiques de niveau recherche, publiés ou non, émanant des établissements d'enseignement et de recherche français ou étrangers, des laboratoires publics ou privés. 


\title{
Hybridization, fertility and herbicide resistance of hybrids between wheat and Aegilops biuncialis
}

\author{
Iñigo LOUREIRo, Concepción Escorial, José María García-BaUdin, Cristina CHUECA*
}

Dpto. Protección Vegetal, Instituto Nacional de Investigación y Tecnología Agraria y Alimentaria (INIA) Ctra. La Coruña Km. 7.5, 28040 Madrid, Spain

(Accepted 6 October 2008)

\begin{abstract}
Genetically modified crops are now grown worldwide and their area of cultivation is increasing yearly. Although transgenic crops offer benefits, several risks have been identified associated with their cultivation. One such risk is their potential for hybridization with wild species, and weed-related species, and the possible escape and subsequent introgression of the transgenes into these species. Transgenic wheat varieties are being successfully developed and field-tested, primarily on herbicide-tolerant wheat. If genetically modified herbicide-tolerant wheat is commercialized in the near future this may result in the escape of the inserted gene from the crop and its incorporation into closely related wild species. This fact could give a competitive advantage to the recipients. For risk assessment purposes it is necessary to determine the frequency of crop-wild transgene flow and the fertility of hybrids. Most wheat-wild hybridization studies have been conducted with the purpose of breeding with wheat acting as the female parent in crosses, but very limited information is available focused on hybrid production with wheat as the male parent. Here, we studied (1) the potential hybridization between wheat and the wild related Aegilops biuncialis, and (2) the fertility of the hybrids. Hybridization was quantified in crossing experiments over 5 years in a greenhouse using three wheat cultivars as pollen donors and emasculated plants of one A. biuncialis population as pollen recipients. Hybridization was estimated as the ratio of number of seeds set to the number of flowers pollinated in percentage terms. Our results show that hybrids between wheat and A. biuncialis are formed easily, with hybridization rates ranging from 8.5 to $75 \%$. The fertility of the hybrids, measured as the number of seeds per spikelet (\%), was also evaluated by self-pollination and by backcrossing. Most of the hybrids were self-sterile but $11 \mathrm{~F}_{2}$ seeds were obtained from 191 A. biuncialis-wheat hybrids. However, backcrossing seeds were found in all $\mathrm{BC}_{1}$ combinations at average rates of 3.7\% (0-19.6\%) for greenhouse experiments, and $4.6 \%(0-28.9 \%)$ for field experiments. In subsequent generations, although few plants were available, $\mathrm{BC}_{1} \mathrm{~F}_{1}$ exhibited a certain degree of fertility, up to $3.57 \%$ with the cultivar Chinese Spring. $\mathrm{F}_{1}$ and $\mathrm{BC}_{1}$ were also checked for resistance to the herbicide difenzoquat that was present in the parental wheat, while A. biuncialis was susceptible. Difenzoquat resistance was maintained in the $\mathrm{F}_{1}$ hybrids and also in the derived $\mathrm{BC}_{1}$ plants. This information on hybridization and fertility of the first $A$. biuncialis-wheat hybrid generations could be an initial step to assess the relative advantage of hybridization in the adaptive ability of A. biuncialis and hybrid derivatives and the impact thereof on the environment and agricultural system. This needs to be studied in depth when wheat and A. biuncialis share habitat.
\end{abstract}

Aegilops biuncialis / wheat / interspecific hybridization / hybrid fertility / herbicide tolerance / gene transfer / risk assessment / herbicide / Difenzoquat / GMO

\section{INTRODUCTION}

Biotechnological advances have made the transference of genes from various classes of organisms into crop plants possible and the result is genetically modified varieties expressing new traits. It is estimated that transgenic crops (mainly soybean, maize, cotton and canola) are cultivated worldwide in an area that has increased from 1.7 million hectares in 1996 to 114.3 million hectares in 2007 , of which more than $70 \%$ have a herbicide-tolerant trait (James, 2007). Wheat (Triticum aestivumL.) is the world's most important crop species, grown on an area of over 210 million hectares and now yielding around

* Corresponding author: chueca@inia.es
607 million tons annually (FAOSTAT, 2008). Transgenic wheat varieties are being successfully developed and fieldtested, primarily on glyphosate-tolerant wheat (Blackshaw and Harker, 2002; Zhou et al., 2003). That makes wheat the next "big" genetically engineered crop to be cultivated if current trade barriers are overcome and regulatory agencies review it favorably.

Herbicide tolerance presents several advantages for farmers (Bonny, 2008): easier weed management with simplified herbicide applications and reduced risk of failed weed control thanks to the post-emergence application of a nonselective and non-residual herbicide that, while facilitating crop rotations, also leads to a decrease in the environmental 
impact of the treatments. The result thus favors a sustainable development. However, there are some concerns related to the introduction of transgenic wheat. The coexistence of transgenic and conventional crops is a major concern (Devos et al., 2007; Loureiro et al., 2007a). Other questions related to herbicide-resistant crops are the potential influence of herbicide applications on crop-associated weeds, the selection of herbicide-resistant weeds, the management of volunteer herbicide-resistant plants and the risk of herbicide resistance transference to other plants (Loureiro, 2005; Bonny, 2008). Thus, before a transgenic crop can be grown under field conditions, a risk assessment must be carried out to determine potential adverse impacts.

The transfer of herbicide resistance transgenes from crops to related species through interspecific hybridization is one of the greatest risks of transgenic herbicide-resistant crops (Dale et al., 2002). Hybridization with wild relatives has been a real issue implicated in the evolution of more aggressive weeds for seven of the world's 13 most important crops (Ellstrand et al., 1999). Hybridization of herbicide-resistant genetically modified wheat with populations of free living relatives could make these plants increasingly difficult to control, especially if they are already recognized as agricultural weeds and if they acquire resistance to widely used herbicides (Darmency, 1994). The transfer of herbicide resistance genes from wheat to Aegilops cylindrica Host., a noxious weed in the wheatproducing areas of the western United States, has been detected in the field and created problems for its control (Seefeldt et al., 1998; Wang et al., 2001; Gandhi et al., 2006).

Aegilops biuncialis Vis. is a winter annual grass closely related to wheat with many tillers and semi-erect culms $20-40 \mathrm{~cm}$ tall. In late spring, plants produce $2-6$ spikelets (2-3 fertile) on spikes that tend to remain together through the summer, breaking into individual spikelets when soaked by fall rains. Seeds are polymorphic and normally germinate within the spikelet but may remain dormant for several seasons. A. biuncialis is present in a great number of European countries and it is particularly frequent in Southern and SouthEastern Europe (van Slageren, et al., 1994). Although invasive, it is generally not considered weedy in the agronomic sense. As a typical colonizer, A. biuncialis populations are commonly found in massive stands close to wheat.

The flowering periods of $A$. biuncialis and wheat overlap in Southern European fields (Zaharieva and Monneveux, 2006). Although Aegilops and wheat are autogamous plants propagated through seeds by self-pollination, cross-pollination can occur and natural hybridization has been detected between the two genera (van Slageren, 1994). In field assays carried out under semiarid conditions, natural hybridization between wheat and A. biuncialis occurred at rates from 0.20 to $0.45 \%$ (Loureiro et al., 2007b). Hybrids will probably occur under favorable conditions in all regions where both parents grow in sympatry, as is the case for hybridization between wheat and Aegilops geniculata Roth. under field conditions in Spain (Loureiro et al., 2006).

Safety assessment activities need base-line information to evaluate the possibility of transgene introgression from cultivated wheat into other varieties, species and wild relatives in order to prevent diffusion of a character (i.e., such as herbicide resistance) that could provide adaptative advantages, making weed and wild species more invasive. This study evaluates the potential for hybridization between T. aestivum and the wild relative A. biuncialis and the ability of the $\mathrm{F}_{1}$ hybrids to reproduce and survive for the $\mathrm{F}_{2}$ and $\mathrm{BC}_{1}$ generations. These are critical factors for introgression and release of the transgenes to the environment.

\section{MATERIALS AND METHODS}

The present study was carried out at the INIA experimental station, Madrid, Spain ( $40^{\circ} 27^{\prime}$ North; $3^{\circ} 44^{\prime}$ West).

\subsection{Plant material}

One accession of the wheat wild relative Aegilops biuncialis Vis. $(2 \mathrm{n}=4 \mathrm{x}=28$ chromosomes, genomic constitution UUMM) and bread wheat Triticum aestivum $\mathrm{L} .(2 \mathrm{n}=6 \mathrm{x}=42$, AABBDD) cultivars Chinese Spring (CS), Deganit and Cas$\tan$ were used in the experiments. The A. biuncialis accession comes from the collection of the Plant Breeding Institute (now John Innes Center). Nomenclature of the wild Aegilops species is according to van Slageren (1994) and the genomic constitution according to Waines and Barnhart (1992).

\subsection{Hybridization study}

To establish the maximum potential rate of hybridization between $A$. biuncialis and wheat under our conditions, manual and open pollination crosses without limits to pollen availability were performed in a greenhouse in which lateral walls were open and temperature and relative humidity were similar to outdoor conditions. To simulate the flow of pollen into wild populations, A. biuncialis plants were used as pollen recipients and wheat plants as donors.

A. biuncialis was crossed for five years with the T. aestivum cultivar Chinese Spring and two years with the cultivars Castan and Deganit. In order to overlap the flowering periods between A. biuncialis and wheat, several sets were sown each year periodically at six 15-day intervals starting each year in early November. Two to three days before anthesis, spikes of the maternal parent were manually emasculated and covered with cellophane bags. Only the two basal flowers of each spikelet were used; the central flowers were removed. Two to four days after emasculation, some spikes were handpollinated. Other spikes were emasculated and surrounded by thirty flowering wheat plants for open pollination. Nonemasculated female spikes were removed; wheat was the only pollen source available. To assess the efficacy of the emasculation technique some spikes were emasculated, bagged and left unpollinated. Unpollinated flowers did not produce seeds. In all cases the seeds were collected at maturity. This crossing program yielded a total of three hybrid types ( 1 recipient $\times 3$ pollinators). Hybridization was estimated as the ratio 
Table I. Meteorological data during the crossing periods between $A$. biuncialis and wheat in the greenhouse and during the overlap pollination periods between $A$. biuncialis $\times$ wheat hybrids and the respective parental wheat cultivars in the field.

\begin{tabular}{|c|c|c|c|c|c|c|}
\hline \multirow{2}{*}{ Year } & \multirow{2}{*}{$\begin{array}{c}\text { Hybridization } \\
\text { period }\end{array}$} & \multicolumn{2}{|c|}{ Mean temperature } & \multicolumn{2}{|c|}{ Rainfall } & \multirow{2}{*}{$\begin{array}{l}\text { Avg. relative } \\
\text { humidity }(\%)\end{array}$} \\
\hline & & Max. & Min. & Days & $\mathrm{mm}$ & \\
\hline \multicolumn{7}{|c|}{ Greenhouse hybrid production } \\
\hline 2002 & 23-27 May & $24.0 \pm 2.6$ & $9.7 \pm 2.8$ & 0 & 0.0 & \pm 4.5 \\
\hline 200 & $20-$ & $28.0 \pm$ & $7.8 \pm$ & 0 & 0.0 & \\
\hline 200 & $20-2$ & $21.7 \pm$ & $11.2 \pm$ & 3 & 41.0 & 71.9 \\
\hline 2005 & 14-22 May & $25.2 \pm 4.4$ & $7.8 \pm 2.9$ & 1 & 0.1 & 43.0 \\
\hline \multicolumn{7}{|c|}{ Field backcrosses } \\
\hline 2005 & 29 May-6 Jun & $27.6 \pm$ & $15.8 \pm 0$. & 2 & 1.2 & 50. \\
\hline 2006 & 27 May-4 Jun & $31.0 \pm 4.3$ & $12.4 \pm 2.7$ & 0 & 0.0 & $30.4 \pm 4.2$ \\
\hline
\end{tabular}

of number of seeds set to the number of flowers pollinated in percentage. Each spike was considered as a replicate. Temperature and humidity data were recorded during the pollination periods (Tab. I).

\subsection{Hybrid identification}

The different ploidy levels of T. aestivum $(2 \mathrm{n}=42)$ and A. biuncialis $(2 \mathrm{n}=28)$ enabled us to detect hybrid plants $(2 \mathrm{n}=35)$ on the basis of their mitotic chromosome number. Chromosome counts were done on roots regenerated in pots in the greenhouse using young shoots from the hybrids. Root meristems were collected from each plant and were pre-treated in $\alpha$-bromonaphthalene at $4{ }^{\circ} \mathrm{C}$ for $16 \mathrm{~h}$, fixed in a $90 \%$ acetic acid solution for $30 \mathrm{~min}$, washed twice with $95^{\circ}$ ethanol and stored in $70^{\circ}$ ethanol. After a minimum of 10-14 days, root meristems were ready to be stained in Schiff reactive for 60 min after a $10-12 \mathrm{~min}$ hydrolysis at $60{ }^{\circ} \mathrm{C} \mathrm{HCl} 1 \mathrm{~N}$ and squashed in a $1 \%$ Belling's aceto-carmine solution prior to light microscopy observation.

The spike morphology also allowed us to identify the hybrid plants.

\subsection{Fertility of the $A$. biuncialis $\times$ wheat hybrids}

$\mathrm{F}_{1}$ hybrid plants produced from each $A$. biuncialis $\times$ wheat combination were sown each year in autumn in the greenhouse and were grown to maturity in order to estimate their fertility. To study the hybrid self-fertility, spikes from $F_{1}$ plants were covered with cellophane bags before anthesis. Backcross fertility was evaluated by surrounding the $F_{1}$ hybrids by thirty plants from the respective wheat pollen donor in bloom.

In 2005 and 2006 we also tested backcross fertility of the hybrids under field simulated conditions. Fifteen $1 \times 1 \mathrm{~m}$ pollinator blocks sowed with $T$. aestivum at field density $\left(400\right.$ seeds $\mathrm{m}^{-2}$ ) were established per wheat cultivar. At wheat bloom, one already-flowering $F_{1}$ hybrid plant was introduced per plot into the respective parental plots. The spikes from hybrid plants that overlap in the flowering with wheat were collected at maturity separately from each individual. Seeds were manually threshed and production per plant was counted. The fertility was estimated as the percentage of seeds per spikelet. Meteorological data were collected annually throughout the pollen source flowering period from a weather station located in the experimental field plot (Tab. I).

\subsection{Screening for herbicide resistance}

Chinese Spring wheat possessing herbicide resistance alleles endowing resistance to difenzoquat, a mitosis inhibitor used for the post-emergence control of wild Avena spp. in winter cereals, was used to obtain hybrid resistant progeny detectable by herbicide selection. It was used instead of transgenic wheat whose use is limited by availability and regulatory constraints. The genetic control of tolerance to difenzoquat in bread wheat is determined by a major single gene (Busch et al., 1989). Aegilops species are susceptible to this herbicide.

A. biuncialis $\times$ Chinese Spring hybrids previously obtained by hand-crossing in the greenhouse were screened for herbicide resistance by herbicide spraying. Seeds of A. biuncialis $\times$ wheat hybrids were sown at appropriate depths in 1-L plastic pots $(10 \mathrm{~cm}$ diameter, 10 seeds per pot) containing soil and sand in a $1: 1(\mathrm{v} / \mathrm{v})$ mixture. A. biuncialis $\times$ Chinese Spring hybrids were treated at the three leaf stage with a commercially formulated difenzoquat (difenzoquat $33 \% \mathrm{w} / \mathrm{v}$ ) at $3 \mathrm{~kg}$ a.i. $\mathrm{ha}^{-1}$, the amount of herbicide recommended in the field. The response to the herbicide difenzoquat was evaluated visually 30 days after treatment.

Dose-response analysis was also conducted on $\mathrm{F}_{1}$ and $\mathrm{BC}_{1}$ hybrids with Chinese Spring. Each herbicide was applied at 0, $0.5,0.75,1,1.5$ and $2 \mathrm{X}(\mathrm{X}=$ recommended dose). The hybrids were extracted with their roots 15 days after treatment, washed with water and roots dried with paper to obtain the fresh weight. Three replicates and 3 seeds per replicate were used in each treatment. A log-logistic model (Seefeldt et al., 1995) was used to analyze the data to predict the trend of herbicide resistance. In this model, the equation $y=f(x)=C+$ $(D-C) /\left(1+\left(x / \mathrm{LD}_{50}\right)^{\mathrm{b}}\right)$ was used to fit the data $\left(\mathrm{LD}_{50}=50 \%\right.$ inhibitory dose, $b=$ slope of the curve at $\mathrm{LD}_{50}, C=$ lower limit and $D=$ upper limit). The LD50 values as $\mathrm{kg}$ a.i. difenzoquat ha ${ }^{-1}$ and the $95 \%$ confidence interval values (C.I.) were determined by SAS analysis. The LD50s whose C.I. values did not overlap were considered to be significantly different.

Herbicide applications were carried out using a Research Track Spray Cabinet (Devries Manufacturing, Hollandale, MN, USA) equipped with a Teejet 8002-E flat fan nozzle calibrated to spray $176 \mathrm{~L} \mathrm{ha}^{-1}$ at $130 \mathrm{kPa}$. After spraying, the pots were placed randomly in the greenhouse. Temperature was maintained at $24 / 16 \pm 2{ }^{\circ} \mathrm{C}$ (day/night temperature).

\subsection{Data analysis}

Data on hybridization (each spike is a replicate) and fertility (each plant is a replicate) rates were subjected to an $\arcsin \sqrt{ } \mathrm{x}$ transformation prior to a multifactorial variance 
Table II. Percentage of hybrid plants obtained after hand and open pollination in the greenhouse. AEBI= Aegilops biuncialis. Hybridization was estimated as the ratio of number of seeds set to the number of flowers pollinated in percentage. Each spike was considered as a replicate. The mean \pm standard deviations of the data from all the years of study have been included.

\begin{tabular}{|c|c|c|c|c|c|c|}
\hline \multirow[t]{2}{*}{ Year } & \multicolumn{2}{|c|}{ AEBI $\times$ Chinese Spring } & \multicolumn{2}{|c|}{ AEBI $\times$ Castan } & \multicolumn{2}{|c|}{ AEBI $\times$ Deganit } \\
\hline & $\begin{array}{c}\text { No. } \\
\text { flowers }\end{array}$ & $\begin{array}{c}\text { Hybridization } \\
(\%)\end{array}$ & $\begin{array}{c}\text { No. } \\
\text { flowers }\end{array}$ & $\begin{array}{c}\text { Hybridization } \\
(\%)\end{array}$ & $\begin{array}{c}\text { No. } \\
\text { flowers }\end{array}$ & $\begin{array}{c}\text { Hybridization } \\
(\%)\end{array}$ \\
\hline \multicolumn{7}{|c|}{ Hand pollination } \\
\hline 2001 & 967 & 9.2 & & & & \\
\hline 2002 & 688 & 12.2 & & & & \\
\hline 2003 & 598 & 33.4 & & & & \\
\hline 2004 & 286 & 29.0 & 280 & 43.2 & 92 & 22.8 \\
\hline 2005 & 290 & 15.5 & 248 & 19.4 & 164 & 11.6 \\
\hline TOTAL & 2829 & $19.9 \pm 10.7$ & 528 & $31.3 \pm 11.9$ & 256 & $17.2 \pm 7.9$ \\
\hline \multicolumn{7}{|c|}{ Open pollination } \\
\hline 2001 & 352 & 42.0 & & & & \\
\hline 2002 & 376 & 8.5 & & & & \\
\hline 2003 & 374 & 30.5 & & & & \\
\hline 2004 & 284 & 75.0 & 196 & 74.8 & & \\
\hline 2005 & 192 & 53.6 & 150 & 28.0 & & \\
\hline TOTAL & 1578 & $41.9 \pm 24.9$ & 346 & $51.5 \pm 33.2$ & & \\
\hline
\end{tabular}

analysis (ANOVA). Year and pollination mode in the hybridization study carried out in the greenhouse and year, parental wheat cultivar and location (in the case of the backcrosses carried out under greenhouse and field simulated conditions) in the hybrid fertility study were used as main factors. When significant differences were found, Newman-Keuls tests were used. Statistical analysis of data used SAS software (SAS Institute Inc., 1999).

\section{RESULTS AND DISCUSSION}

\subsection{Greenhouse hybridization study}

Hybridization was not particularly difficult and interspecific hybrids were recovered from all crosses (Tab. II). Mitotic metaphases revealed the expected hybrid chromosome number $2 \mathrm{n}=5 \mathrm{x}=35$ (ABDUM). The spike morphology of interspecific hybrids was intermediate to the parental species (Fig. 1). Hybrids showed vigorous vegetative growth and good tillering ability.

Table II shows the seed set data for hand and open pollination between $A$. biuncialis and the wheat cultivars Chinese Spring, Castan and Deganit. The results revealed great differences in crossability between pollination modes $\left(F_{1,460}=\right.$ $25.13, P<0.05)$ and between years $\left(F_{4,460}=15.49, P<0.05\right)$ in both pollination experiments. The highest seed set, from 29.0 to $43.2 \%$ in hand pollination and up to $75 \%$ in open pollination, was obtained in 2004. In 2005, the seed set ranged from 11.6 to $19.4 \%$ and from 28.0 to $53.6 \%$ in hand and open pollination, respectively. The seed set was lower, always below $12.2 \%$, in 2001 and 2002 hand crosses carried out only with Chinese Spring. These differences could primarily be attributed to environmental conditions whose variations strongly influence cross-pollination (de Vries, 1974; Loureiro et al.,

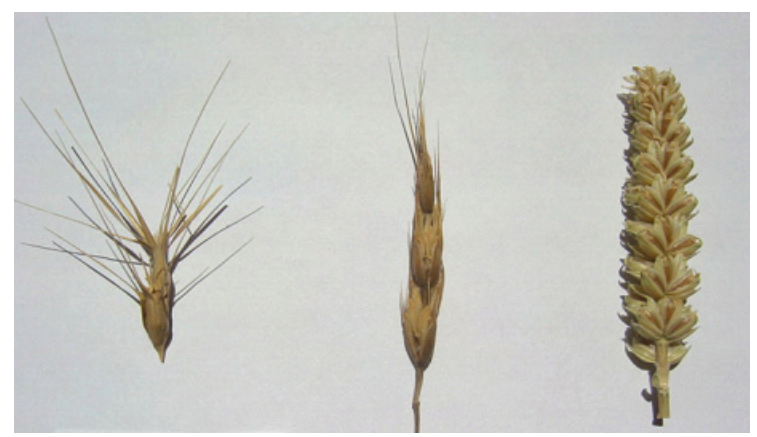

Figure 1. Morphology of the hybrid spikes (center) between A. biuncialis (left) and Triticum aestivum cv Chinese Spring (right). $\mathrm{F}_{1}$ hybrids can easily be distinguished morphologically from their parents at the spike stage.

2007a). In 2004 the mean relative humidity of the six-day crossing period was $71.9 \pm 12.6 \%$ (three days with rainfall) and the average temperature was $21.7 \pm 1.4{ }^{\circ} \mathrm{C}$ (Tab. I); these conditions are favorable for crossability (de Vries, 1974). In 2002 and 2003 the weather was less favorable, with higher temperatures (up to averages of $28 \pm 4.4{ }^{\circ} \mathrm{C}$ ) and lower humidity (<46\%) (Tab. I). Aegilops and/or the wheat genotypes could also be involved in the success of the hybridization and could influence crossability (Farooq et al., 1989; Hedge and Waines, 2004).

In order to evaluate the potential risk of gene flow, crossability studies must be carried out with wheat acting as pollen donor. There are few studies on the hybridization between A. biuncialis and wheat in this sense of crossing since most of the existing studies have been produced for wheat breeding purposes and show data with wheat as pollen recipient (Jacot et al., 2004). Our data show that these two species 
Table III. Seed set on A. biuncialis (AEBI) $\times$ wheat hybrids after selfing under greenhouse conditions. CS $=$ Chinese Spring.

\begin{tabular}{|c|c|c|c|c|c|c|c|}
\hline $\mathrm{F}_{1}$ Hybrid & Year & $\begin{array}{l}\text { Plants } \\
\text { (No) }\end{array}$ & Spikes/plant & $\begin{array}{c}\text { No. spikelets } \\
\text { (Spikelets/spike) }\end{array}$ & $\begin{array}{c}\text { Seed } \\
\text { set }\end{array}$ & $\begin{array}{c}\text { Fertility (\% } \\
\text { seeds/spikelet) } \\
\text { (Range) }\end{array}$ & $\begin{array}{c}\% \text { Plants } \\
\text { with seeds }\end{array}$ \\
\hline \multirow[t]{4}{*}{$\mathrm{AEBI} \times \mathrm{CS}$} & 2002 & 44 & $11.6 \pm 5.8$ & $\begin{array}{c}3236 \\
(6.6 \pm 0.9)\end{array}$ & 4 & $\begin{array}{c}0.12 \\
(0-1.61)\end{array}$ & 9 \\
\hline & 2003 & 58 & $9.1 \pm 3.6$ & $\begin{array}{c}3169 \\
(5.9 \pm 0.9)\end{array}$ & 1 & $\begin{array}{c}0.03 \\
(0-0.90)\end{array}$ & 2 \\
\hline & 2004 & 24 & $9.3 \pm 5.7$ & $\begin{array}{c}1386 \\
(6.2 \pm 0.8)\end{array}$ & 2 & $\begin{array}{c}0.14 \\
(0-4.34)\end{array}$ & 4.2 \\
\hline & 2006 & 15 & $8.6 \pm 2.9$ & $\begin{array}{c}1006 \\
(6.5 \pm 0.8)\end{array}$ & 0 & 0 & 0 \\
\hline \multirow[t]{2}{*}{ AEBI $\times$ Castan } & 2005 & 15 & $8.2 \pm 3.1$ & $\begin{array}{c}774 \\
6.4 \pm 0.6)\end{array}$ & 0 & 0 & 0 \\
\hline & 2006 & 10 & $6.1 \pm 2.2$ & $\begin{array}{c}506 \\
(6.8 \pm 0.8)\end{array}$ & 1 & $\begin{array}{c}0.19 \\
(0-1.89)\end{array}$ & 10 \\
\hline AEBI $\times$ Deganit & 2005 & 10 & $9.0 \pm 4.9$ & $\begin{array}{c}409 \\
(4.7 \pm 0.3)\end{array}$ & 2 & $\begin{array}{c}0.49 \\
(0-2.30)\end{array}$ & 10 \\
\hline TOTAL & & 191 & & 11682 & 11 & 0.09 & \\
\hline
\end{tabular}

can hybridize easily: this is the first step to understanding the mechanisms of gene flow. Our data, obtained under greenhouse conditions and using emasculation, show the potential maximum hybridization that is possible between the two species and allow risk assessors to hypothesize on the likelihood of hybridization and to go beyond the initial sexual barrier. Such data need to be interpreted cautiously, because the frequency of such an event under field conditions is likely to be much lower. However, hybrids between wheat and A. biuncialis have been found in A. biuncialis natural populations in Lebanon (van Slageren, 1994).

\subsection{Fertility of $\boldsymbol{A}$. biuncialis $\times$ wheat hybrids}

A. biuncialis-wheat $\mathrm{F}_{1}$ hybrids are pentaploid with an unbalanced chromosome number in the gametes produced by the lack of chromosome pairing during meiosis. Most of the $\mathrm{F}_{1} \mathrm{~s}$ produced were completely self-sterile (Tab. III). However, eleven $\mathrm{F}_{2}$ seeds were obtained from the 191 hybrids produced from all $A$. biuncialis $\times$ wheat combinations. Neither the year $\left(F_{4,190}=1.26, P=0.29\right)$ nor the parental wheat cultivar genotype $\left(F_{2,190}=0.54, P=0.58\right)$ influenced the selffertility of the $F_{1}$ hybrids. Self-fertility varied from 0 to $0.14 \%$ seeds spikelet ${ }^{-1}$ for the five-year study of $A$. biuncialis $\times$ Chinese Spring. In the case of $A$. biuncialis $\times$ Castan self-fertility ranged from 0 to $0.19 \%$ for the two years of study, while it was 0 to $0.49 \%$ for the hybrids with Deganit. Some $F_{1}$ hybrids were quite fertile and self-fertility applied to individual plant values ranged from 0 to $4.34 \%$ for the 156 Chinese Spring hybrids, to $1.89 \%$ for the 25 hybrids with Castan and $2.30 \%$ for the 10 hybrids with Deganit.

Hybridization frequency is the very first point for interspecific gene flow; a second point is the ability of the hybrids to reproduce and survive in nature for the first generations. Both issues are limiting factors in terms of introgres- sion. As with the $\mathrm{F}_{1}$ hybrids obtained between wheat and $A$. cylindrica, most of the $\mathrm{F}_{1} \mathrm{~s}$ produced were completely selfsterile (Zemetra et al., 1998). Hybrid sterility is expected in crosses among different ploidy and is associated with problems of chromosome pairing in meiosis. However, in this case few $\mathrm{F}_{2}$ descendants can be produced. The production of fertile hybrids indicates that transgenes with herbicide resistance may escape from the crop plants.

$\mathrm{BC}_{1}$ seeds were found in all combinations when $A$. biuncialis $\times$ wheat hybrids were introduced for open pollination in a cloud of wheat pollen formed by many plants of their respective parental cultivars. The results of the backcrosses proved the female fertility of the hybrids (Tab. IV). The ANOVA conducted on data in 2005 and 2006 showed statistical differences between the two years $\left(F_{1,54}=19.59, P<0.05\right)$. There were also differences among the wheat cultivars involved in the crosses $\left(F_{2,54}=23.52, P<0.05\right)$. The average percentages of seed set by backcrossing were higher in 2005 with values of $9.79 \%$ for Chinese Spring, 3.64\% for Castan and 1.52\% for Deganit (Tab. IV), while in 2006 these values varied from $1.98 \%$ to $3.88 \%$ (Tab. IV). From $60 \%$ of the $A$. biuncialis $\times$ Deganit plants to $100 \%$ in the case of $A$. biuncialis $\times$ Chinese Spring plants were female fertile, with great variability in fertility among plants with ranges from 0 to $19.67 \%$ for the backcrosses with Chinese Spring, to $7.69 \%$ for Castan and $3.63 \%$ for Deganit.

Under field simulated conditions the A. biuncialis-wheat hybrids also produced $\mathrm{BC}_{1}$ seeds successfully with the three wheat cultivars (Tab. V). As in the greenhouse, backcrossing rates were higher in the year 2005 than in $2006\left(F_{1,49}=33.48\right.$, $P<0.05)$. In the 2005 overlap in the flowering periods, the mean daily maximum temperatures were $26.1 \pm 4.9{ }^{\circ} \mathrm{C}$ and relative humidity levels averaged $50.1 \pm 13.2 \%$ ( 2 days of rainfall, with $1.2 \mathrm{~mm})$. In 2006 the mean maximum temperature was $31.0 \pm 4.3{ }^{\circ} \mathrm{C}$ and relative humidity averaged $30.4 \pm 4.2 \%$ 
Table IV. $\mathrm{BC}_{1}$ seed set on A. biuncialis (AEBI) $\times$ wheat hybrids after backcrossing with the T. aestivum cultivars Chinese Spring (CS), Castan and Deganit under greenhouse conditions.

\begin{tabular}{|c|c|c|c|c|c|c|c|}
\hline Backcross & Year & $\begin{array}{c}\text { Plants } \\
\text { (No) }\end{array}$ & Spikes/plant & $\begin{array}{c}\text { No. spikelets } \\
\text { (Spikelets/spike) }\end{array}$ & $\begin{array}{c}\text { Seed } \\
\text { set }\end{array}$ & $\begin{array}{c}\text { Fertility (\% } \\
\text { seeds/spikelet) } \\
\text { (Range) }\end{array}$ & $\begin{array}{c}\% \text { Plants } \\
\text { with seeds }\end{array}$ \\
\hline \multirow[t]{2}{*}{$\begin{array}{c}(\mathrm{AEBI} \times \mathrm{CS}) \\
\times \mathrm{CS}\end{array}$} & 2005 & 15 & $10.5 \pm 4.2$ & $\begin{array}{c}1082 \\
(6.8 \pm 0.7)\end{array}$ & 106 & $\begin{array}{c}9.79 \\
(4.76-19.67)\end{array}$ & 100 \\
\hline & 2006 & 10 & $6.7 \pm 1.7$ & $\begin{array}{c}460 \\
(6.9 \pm 0.3)\end{array}$ & 18 & $\begin{array}{c}3.88 \\
(0-8.5)\end{array}$ & 90 \\
\hline $\begin{array}{c}(\mathrm{AEBI} \times \text { Castan }) \\
\times \text { Castan }\end{array}$ & 2005 & 10 & $7.5 \pm 2.1$ & $\begin{array}{c}577 \\
(7.7 \pm 0.2)\end{array}$ & 21 & $\begin{array}{c}3.64 \\
(0-7.69)\end{array}$ & 90 \\
\hline $\begin{array}{c}(\mathrm{AEBI} \times \text { Deganit }) \\
\times \text { Deganit }\end{array}$ & 2005 & 10 & $7.6 \pm 1.9$ & $\begin{array}{c}460 \\
(6.1 \pm 0.6)\end{array}$ & 7 & $\begin{array}{c}1.52 \\
(0-3.63)\end{array}$ & 60 \\
\hline TOTAL & & 55 & & 3033 & 161 & 5.30 & \\
\hline
\end{tabular}

Table V. $\mathrm{BC}_{1}$ seed set on A. biuncialis (AEBI) $\times$ wheat hybrids after backcrossing with the T. aestivum cultivars Chinese Spring (CS), Castan and Deganit under field simulated conditions.

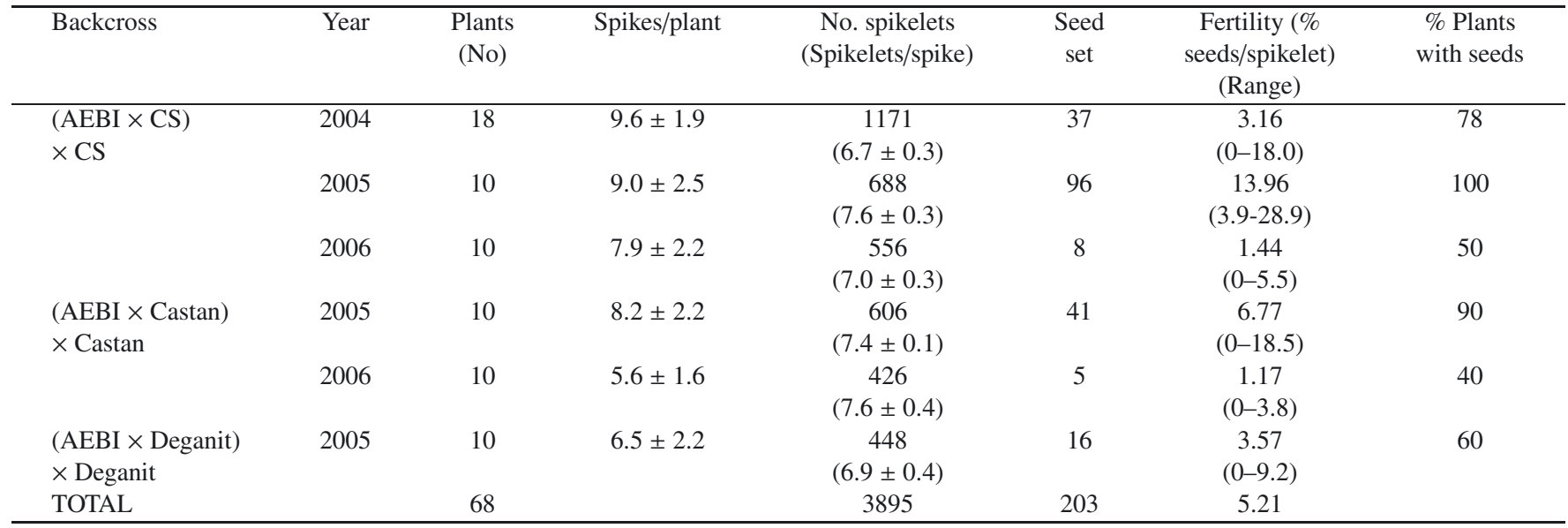

(no rainfall) (Tab. I). The highest seed set rates were those of 2005 with $13.96 \%$ and $6.77 \%$ for the hybrids with Chinese Spring and Castan and $3.57 \%$ with Deganit (Tab. V). There was also a great variability among plant fertilities in all the combinations, up to $28.9 \%$ in some hybrids, while others did not produce seeds. The wheat genotypes influenced the fertility $\left(F_{2,49}=9.37, P<0.05\right)$ and backcrosses with Deganit were less fertile than those obtained with the other cultivars. As occurred in the backcrosses in the greenhouse the percentage of fertile plants varied, depending on the year and combination, from 40 to $100 \%$ (Tab. V). In $\mathrm{BC}_{1}$ the variability observed may be explained on the basis of the different genetic combinations produced. There were no significant differences between the seed set on $A$. biuncialis $\times$ wheat $\mathrm{F}_{1}$ hybrids after backcrossing with wheat under field simulated conditions (Tab. V) and the seed set obtained in the greenhouse (Tab. IV) $\left(F_{1,122}=1.11, P=0.29\right)$, although the wheat plant density under field conditions was greater than that in the greenhouse.

In the experiments reported in this article, $\mathrm{BC}_{1}$ seeds with Deganit were detected at $3.57 \%$. These results are very similar to the $3.17 \%$ reported in our earlier work with Deganit wheat under field experimental conditions (Loureiro et al., 2007b). In general, the BC1 seed set obtained with the wheat cultivars employed is of the order of those reported for A. cylindrica by Snyder et al. (2000), who found seed sets of 1.8\% (1-2.5\%) and $6 \%(3-9.2 \%)$ in a two-year experiment, and higher than the $1 \%$ found by Morrison et al. (2002). The transmission of transgenes from the crop through successive backcross generations is an issue that must be addressed when assessing the likelihood of gene flow from transgenic crops to wild relatives.

\subsection{Screening for herbicide resistance}

Figure 2 shows the response to difenzoquat of the parental genotypes and the hand-made $\mathrm{F}_{1}$ hybrids used in the herbicide screening. The damage produced by the herbicide to the growth of the A. biuncialis susceptible plants was apparent 21 days after treatment. The herbicide killed the $A$. biuncialis plants 30 days after treatment, while the Chinese Spring tolerant cultivar and the $\mathrm{F}_{1}$ hybrid plants survived the treatments. The results indicated that the bioassay was adequate for detecting hybrids and demonstrated that herbicide resistance from 
Table VI. Fertility of the $\mathrm{BC}_{1} \mathrm{~F}_{1}$ generation subsequent to the hybrid $\mathrm{AEBI}=$ A. biuncialis, $\mathrm{CS}=\mathrm{Chinese}$ Spring .

\begin{tabular}{|c|c|c|c|c|c|c|c|}
\hline & & $\begin{array}{l}\text { Plants } \\
\text { (No) }\end{array}$ & Spikes/plant & $\begin{array}{c}\text { No. spikelets } \\
\text { (Spikelets/spike) }\end{array}$ & $\begin{array}{c}\text { Seed } \\
\text { set }\end{array}$ & $\begin{array}{c}\text { Fertility (\% } \\
\text { seeds/spikelet) } \\
\text { (Range) }\end{array}$ & $\begin{array}{c}\% \text { Plants } \\
\text { with seeds }\end{array}$ \\
\hline $\mathrm{AEBI} \times \mathrm{CS}$ & $\mathrm{BC}_{1} \mathrm{~F}_{1}$ & 7 & $5.3 \pm 3.5$ & $\begin{array}{c}304 \\
(8.3 \pm 1.8)\end{array}$ & 2 & $\begin{array}{c}0.66 \\
(0-3.57)\end{array}$ & 29 \\
\hline AEBI $\times$ Castan & $\mathrm{BC}_{1} \mathrm{~F}_{1}$ & 5 & $6.5 \pm 2.1$ & $\begin{array}{c}281 \\
(9.2 \pm 1.2)\end{array}$ & 2 & $\begin{array}{c}0.71 \\
(0-2.5)\end{array}$ & 40 \\
\hline TOTAL & & 12 & & 585 & 4 & 0.68 & \\
\hline
\end{tabular}

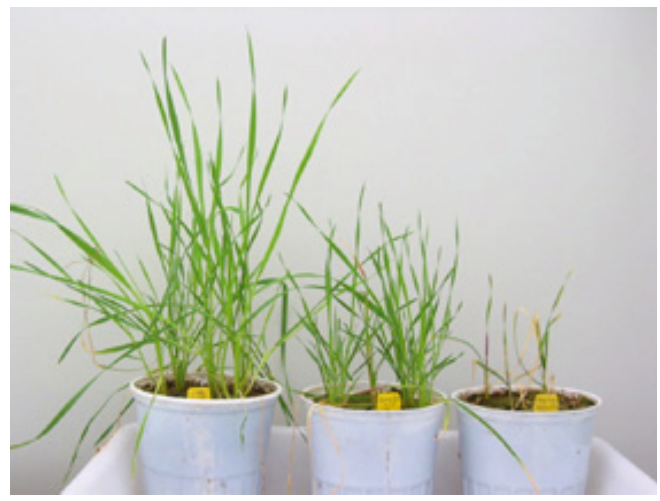

Figure 2. Response to the herbicide difenzoquat $\left(3 \mathrm{~kg}\right.$ a.i. $\left.\mathrm{ha}^{-1}\right)$ 30 days after treatment of Triticum aestivum cv Chinese Spring (left), A. biuncialis (right) and their $\mathrm{F}_{1}$ hybrids. The herbicide application allows the identification of the hybrids.

wheat can be transferred and maintained in the hybrids between A. biuncialis and wheat. This kind of bioassay will be useful for the identification of hybrids in Aegilops wild populations growing near fields sown with wheat carrying a dominant trait for resistance to herbicides and in the quantification of the rate of hybridization.

The difenzoquat dose-response curves (Fig. 3A) showed that injury rating of susceptible $A$. biuncialis was around $70 \%$ for the recommended dose. The $\mathrm{LD}_{50}$ was 1.94 (95\% confidence intervals of 1.56-2.26) and $2.55(2.43-3.08) \mathrm{kg}$ a.i. ha ${ }^{-1}$ for the response of $A$. biuncialis and $\mathrm{F}_{1}$ hybrids with Chinese Spring, respectively. For $\mathrm{BC}_{1} \mathrm{~s}$ the $\mathrm{LD}_{50}$ was $2.85 \mathrm{~kg}$ a.i. $\mathrm{ha}^{-1}$

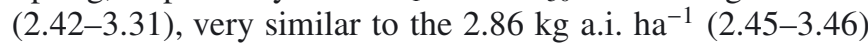
of the Chinese Spring wheat parental cultivar, indicating that herbicide resistance remains in the plants following the $F_{1}$ generation. Figures 3B, 3C and 3D show the difenzoquat doseresponse of A. biuncialis, $\mathrm{F}_{1}$ hybrids and the Chinese Spring wheat cultivar, respectively. The $F_{1}$ hybrids were heterozygous for the resistance gene but exhibited tolerance to a degree that allowed for survival after treatment with difenzoquat.

The partial dominance of the resistance trait could influence the fitness value and introgression rate of the resistance allele in an A. biuncialis population exposed to herbicide selection pressure. As hybrids can maintain herbicide resistance from wheat, the spread of these plants will be favored by the use of the herbicide. This risk has been intensively studied for $A$. cylindrica-wheat hybrids. Several studies prove that crosses are possible and progenies fertile and resistant to the tested herbicide. As a consequence, genes escape, making herbicide- resistant weed development a real risk (Zemetra et al., 1998; Snyder et al., 2000; Guadagnolo et al., 2001; Wang et al., 2001; Morrison et al., 2002; Hedge and Waines, 2004). Similar responses have not been demonstrated for A. biuncialis-wheat, mainly because few studies have been done.

\subsection{Fertility of the subsequent generations}

The self-fertility of the $\mathrm{BC}_{1}$ hybrids $\left(\mathrm{BC}_{1} \mathrm{~F}_{1}\right)$ was also evaluated. This first backcross generation is not completely sterile: two of the seven $\mathrm{BC}_{1}$ hybrids produced with Chinese Spring and Castan had a certain degree of fertility (up to $3.57 \%$ ), with an average of 0.66 and $0.71 \%$, respectively (Tab. VI). The low number of plants available limited the scope of this study. A greater number of plants would be needed to have a better estimate of the fertility of these subsequent generations.

Figure 4 shows overall fertility of the hybrids between $A$. biuncialis and three wheat cultivars averaged over the years of the study. Fertility of the $F_{1}$ generation was low, with a selffertility calculated at $0.094 \%$ ( 11 seeds in 11682 spikelets, from 191 hybrids), while the female fertility estimated by backcrossing was 5.3\% under greenhouse and $5.21 \%$ under field conditions, respectively. The $\mathrm{BC}_{1}$ self-fertility was $0.68 \%$ for the backcrosses with Castan and Chinese Spring. It can be noted that these average self-fertilities increased from $F_{1}$ to the $\mathrm{BC}_{1}$ generation. With A. biuncialis as male parent in the backcrosses, $\mathrm{BC}_{1}$ seeds can also be formed (not shown here, work in progress).

These fertility data allow us to judge the long-term viability and fertility of the hybrids. There appear to be certain similarities with A. cylindrica, for instance: (1) the hybrids can be formed under natural conditions (van Slageren, 1994); (2) the hybrids exhibit a low level of self-fertility $(0.09 \%)$; (3) the hybrids can backcross with wheat under greenhouse and field conditions, producing plants with a female fertility of up to $28.9 \%$; (4) the BC1 plants can demonstrate up to $3.57 \%$ self-fertility, and (5) backcrossing with A. biuncialis acting as male is also possible. Although A. biuncialis does not have genomes in common with wheat, it is known that pairing between chromosomes, besides by wheat cultivars (Martinez et al., 2005; Cifuentes et al., 2006), can be promoted by some Aegilops species, among them A. geniculata, since it has similar genomes (MMUU) to A. biuncialis, (Lacadena and Aspiazu, 1969; Fernandez-Calvin and Orellana, 1992). This fact, together with the fertility evinced by the hybrids, could favor the risk of introgression. 

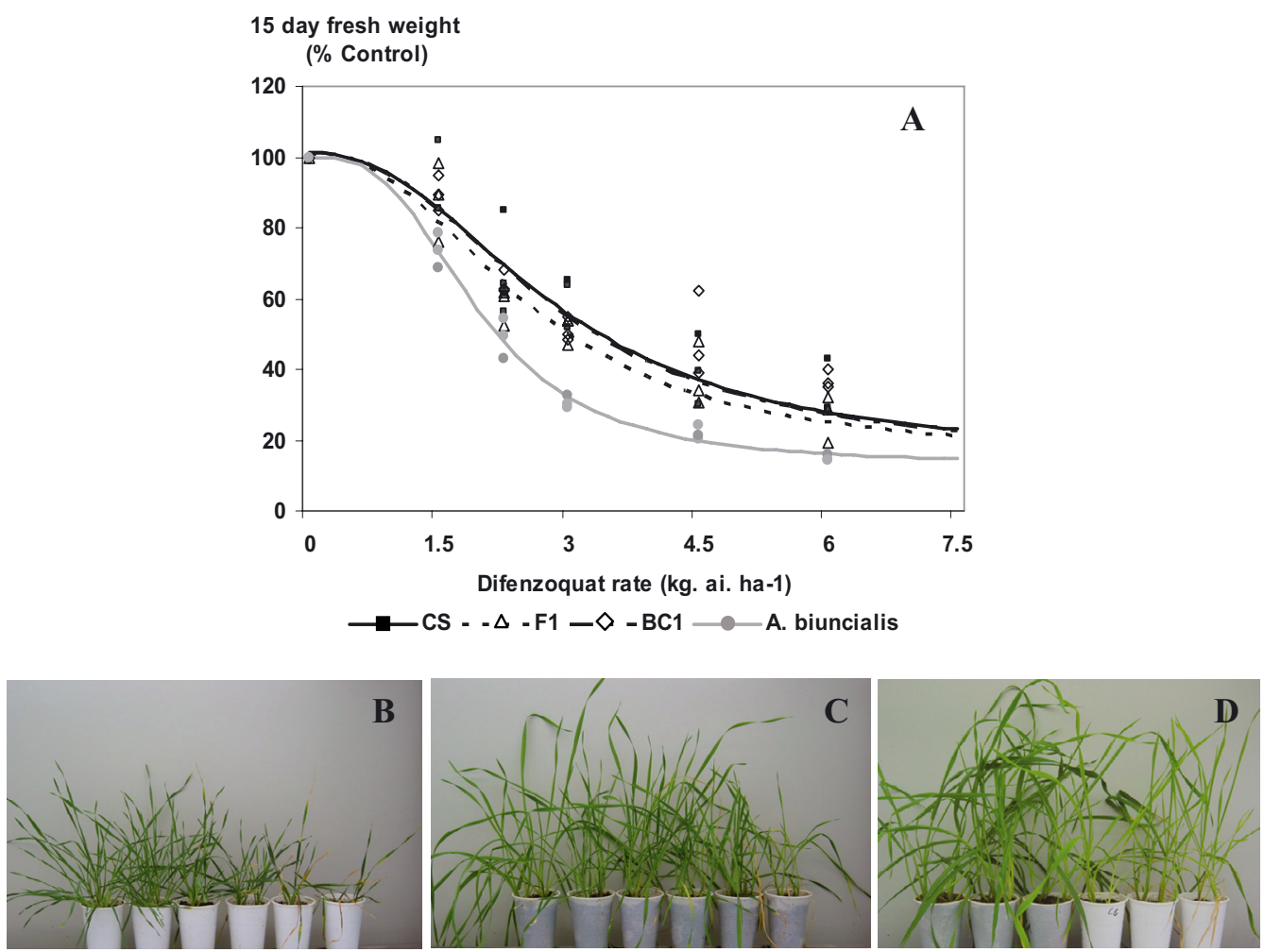

Figure 3. (A) Difenzoquat dose-response curves of A. biuncialis, $\mathrm{F}_{1}, \mathrm{BC}_{1}$ and the $\mathrm{CS}$ wheat cultivar. Dose-response curves were $\mathrm{Y}=14.8+$ $86.3 /\left(1+(\mathrm{x} / 2.85)^{2.3}\right.$ for Chinese Spring, $\mathrm{Y}=14.8+86.3 /\left(1+(\mathrm{x} / 2.55)^{2.3}\right.$ for $\mathrm{F}_{1}$ hybrids, $\mathrm{Y}=14.8+86.3 /\left(1+(\mathrm{x} / 2.82)^{2.3}\right.$ for $\mathrm{BC} \mathrm{C}_{1}$ hybrids and

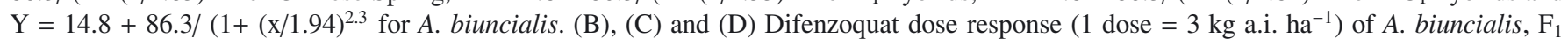
hybrids and the Chinese Spring wheat cultivar, respectively.

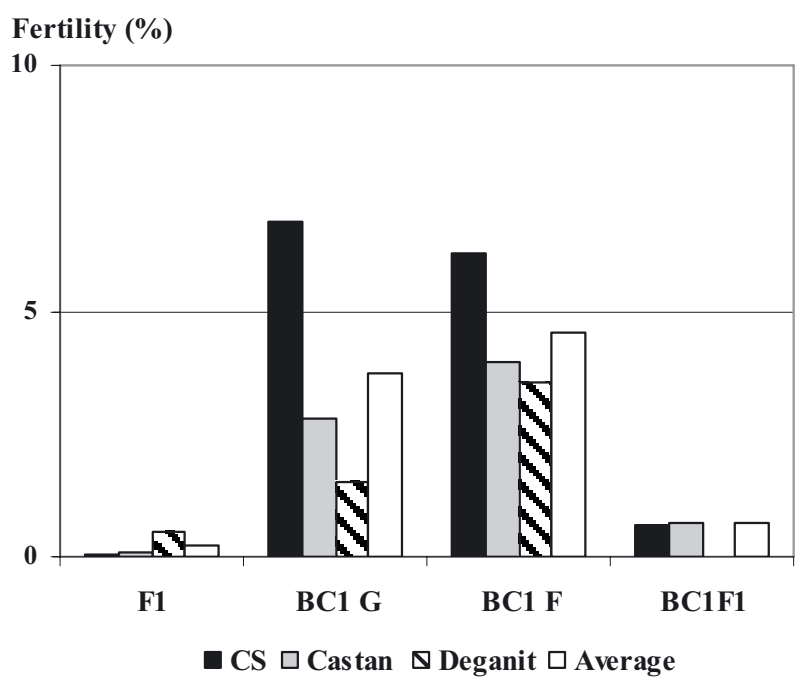

Figure 4. Fertility by selfing $\left(\mathrm{F}_{1}\right)$ and backcrossing under greenhouse $\left(\mathrm{BC}_{1} \mathrm{G}\right)$ and simulated field conditions $\left(\mathrm{BC}_{1} \mathrm{~F}\right)$ of the $A$. biuncialis $\times$ wheat hybrids, and fertility by selfing of the $\mathrm{BC}_{1}$ generation.

\section{CONCLUSION}

In a scenario of herbicide-tolerant wheat cropping, the transference and persistence of resistance genes could represent a threat to the agricultural system and to the environment. The data presented in this article provides further knowledge of potential A. biuncialis-wheat gene transference behavior. The ability to hybridize, the partial fertility of A. biuncialiswheat $\mathrm{F}_{1}$ hybrids, the expression of herbicide tolerance genes in the cytoplasmic background of A. biuncialis, the successful backcross seed production and the potential genetic exchanges between the chromosomes of the two species could facilitate the transfer of herbicide resistance from cultivated wheat to $A$. biuncialis. This may well give these plants a selective advantage to add to their morphological and physiological characteristics, thus increasing the weediness of this species, always in an agronomic scenario of herbicide-tolerant wheat. The fertility and fitness of the hybrids and their progenies must be the subject of supplementary research. The introgression of the herbicide resistance genes into the wild species, in order to adequately assess any potential risk of gene transfer, must also be studied further.

Acknowledgements: This work was supported by INCO-DC contract No. ERB IC18-CT98-0391 and has also received financial support from the Comisión Interministerial de Ciencia y Tecnología (CICYT) of Spain, project AGL2004-07101-C02-01/AGR.

\section{REFERENCES}

Blackshaw R.E., Harker K.N. (2002) Selective weed control with glyphosate in glyphosate-resistant spring wheat (Triticum aestivum), Weed Technol. 16, 885-892. 
Bonny S. (2008) Genetically modified glyphosate-tolerant soybean in the USA: adoption factors, impacts and prospects. A review, Agron. Sustain. Dev. 28, 21-32.

Busch R., Behrens R., Ageez A., Elakkad M. (1989) Inheritance of tolerance to, and agronomic effects of, difenzoquat herbicide in spring wheat, Crop Sci. 29, 47-50.

Cifuentes M., Blein M., Benavente E. (2006) A cytomolecular approach to assess the potential of gene transfer from a crop (Triticum turgidum L.) to a wild relative (Aegilops geniculata Roth.), Theor. Appl. Genet. 112, 657-664.

Dale P.J., Clarke B., Fontes E.M.G. (2002) Potential for the environmental impact of transgenic crops, Nat. Biotech. 20, 567-580.

Darmency H. (1994) The impact of hybrids between genetically modified crop plants and their related species - introgression and weediness, Mol. Ecol. 3, 37-40.

de Vries A.P. (1974) Some aspects of cross-pollination in wheat (Triticum aestivum L.). 4. Seed set on male sterile plants as influenced by distance from the pollen source, pollinator:male sterile ratio and width of the male sterile strip, Euphytica 23, 601-622.

Devos Y., Reheul D., Thas O., De Clercq E.M., Cougnon M., Cordemans K. (2007) Implementing isolation perimeters around genetically modified maize fields, Agron. Sustain. Dev. 27, 155-165.

Ellstrand N.C., Prentice H.C., Hancock J.F. (1999) Gene flow and introgression from domesticated plants into their wild relatives, Ann. Rev. Ecol. Syst. 30, 539-563.

FAOSTAT (2008) FAO Statistic Database, http://faostat.fao.org.

Farooq S., Iqbal N., Shah T.M. (1989) Intergeneric hybridization for wheat improvement. I. Influence of maternal and paternal genotypes on hybrid production, Cer. Res. Comm. 17, 17-22.

Fernandez-Calvin B., Orellana J. (1992) Relationships between pairing frequencies and genome affinity estimations in Aegilops ovata $\times$ Triticum aestivum hybrid plants, Heredity, 68, 165-172.

Gandhi H.T., Mallory-Smith C.A., Watson C.J.W., Zemetra R.S., RieraLizarazu O. (2006) Hybridization between wheat and jointed goatgrass (Aegilops cylindrica) under field conditions, Weed Sci. 54, 1073-1079.

Guadagnolo R., Savova-Bianchi D., Felber F. (2001) Gene flow from wheat (Triticum aestivum L.) to jointed goatgrass (Aegilops cylindrica Host), as revealed by RAPD and microsatellite markers, Theor. Appl. Genet. 103, 1-8.

Hedge S.G., Waines J.G. (2004) Hybridization and introgression between bread wheat and wild and weedy relatives in North America, Crop Sci. 44, 1145-1155.

Jacot Y., Ammann K., Rufener Al Mazyad P., Chueca C, David J., Gressel J., Loureiro I., Wang H., Benavente E. (2004) Hybridization between wheat and wild relatives, a European Union research programme, in: den Nijs D.B.H., Bartsch D., Sweet J. (Eds.), Introgression from Genetically Modified Plants into Wild Relatives, CABI Publishing, UK.

James, C. (2007) Global Status of Commercialized Biotech/GM Crops: 2007, ISAAA Brief No 37, ISAAA: Ithaca, NY.

Lacadena J.R., Aspiazu A. (1969) Introduction of alien variation into wheat by gene recombination. II. Action of the $5 \mathrm{~B}$ genetic system on the meiotic behaviour of mono 5B Triticum aestivum $\mathrm{L}$. $\times$ Aegilops ovata L. hybrids. Genét. Ibér. 22, 1-10.

Loureiro I. (2005) Estudio del riesgo potencial agrícola y medioambiental del cultivo de trigo tolerante a herbicidas, MS Thesis, Universidad Complutense de Madrid, Madrid, Spain.

Loureiro I., Escorial M.C., García-Baudín J.M., Chueca M.C. (2006) Evidence of natural hybridization between Aegilops geniculata and wheat under field conditions in Central Spain, Environ. Biosafety Res. 5, 105-109.

Loureiro I., Escorial M.C., García-Baudín J.M., González-Andujar J.L., Chueca M.C. (2007a) Wheat pollen dispersal under semiarid field conditions. Potential outcrossing with Triticum aestivum and Triticum turgidum, Euphytica 156, 25-37.

Loureiro I., Escorial M.C., García-Baudín J.M., Chueca M.C. (2007b) Hybridization between wheat (Triticum aestivum) and the wild species Aegilops geniculata and A. biuncialis under experimental field conditions, Agr. Ecosyst. Environ. 120, 384-390.

Martinez M., Cuadrado C., Laurie D.A., Romero C. (2005) Synaptic behaviour of hexaploid wheat haploid with different effectiveness of the diploidizing mechanism, Cytogen. Genome Res. 109, 210-214.

Morrison L.A., Riera-Lizarazu O., Cremieux L., Mallory-Smith C.A. (2002) Jointed goatgrass (Aegilops cylindrica Host) $\times$ wheat (Triticum aestivum L.) hybrids: hybridization dynamics in Oregon wheat fields, Crop Sci. 42, 1863-1872.

SAS (1999) Statistical Analysis System, Version 8.1, SAS Institute Inc., Cary, NC, USA.

Seefeldt S.S., Jensen J.E., Fuerst E.P. (1995) Log-logistic analysis of herbicide dose-response relationships, Weed Technol. 9, 218-227.

Seefeldt S.S., Zemetra R., Young F.L., Jones S.S. (1998) Production of herbicide resistant jointed goatgrass (Aegilops cylindrica) $\times$ wheat (Triticum aestivum) hybrids in the field by natural hybridization, Weed Sci. 46, 632-634.

Snyder J.R., Mallory Smith C.A., Balter S. (2000) Seed production on Triticum aestivum by Aegilops cylindrica hybrids in the field, Weed Sci. 48, 588-593.

van Slageren M.W. (1994) Wild wheats: a monograph of Aegilops L. and Ambylopyrum (Jaub. \& Spach.) Eig (Poaceae), Wageningen Agricultural University and ICARDA, Wageningen.

Waines J.G., Barnhart D. (1992) Biosystematic research in Aegilops and Triticum, Hereditas 116, 207-212.

Wang Z., Zemetra R.S., Hansen J., Mallory-Smith C.A. (2001) The fertility of wheat $\times$ jointed goatgrass hybrid and its backcross progenies, Weed Sci. 49, 340-345.

Zaharieva M., Monneveux P. (2006) Spontaneous hybridization between bread wheat (Triticum aestivum L.) and its relatives in Europe, Crop Sci. 46, 512-527.

Zemetra R.S., Hansen J., Mallory-Smith C.A. (1998) Potential for gene transfer between wheat (Triticum aestivum) and jointed goatgrass (Aegilops cylindrica), Weed Sci. 46, 313-317.

Zhou H.., Berg J.D., Blank S.E., Chay C.A., Chen G., Eskelsen S.R., Fry J.E., Hoi S., Hu T., Isakson P.J., Lawton M.B., Metz S.G., Rempel C.B., Ryerson D.K., Sansone A.P., Shook A.L., Starke R.J., Tichota J.M.,Valenti S.A. (2003) Field efficacy assessment of transgenic Roundup Ready wheat, Crop Sci. 43, 1072-1075. 